\title{
EHMTI-0371. A new physical sign in migraine 'pointing forehead'
}

\author{
S Samarakoon*, A Munasinghe \\ From 4th European Headache and Migraine Trust International Congress: EHMTIC 2014 \\ Copenhagen, Denmark. 18-21 September 2014
}

\section{Objectives}

This study was designed to compare the presence of seven clinical signs in a group of patients with migraine with that of patients with non-migraine headache.

\section{Background}

Migraine is sometimes misdiagnosed. Therefore additional features are useful to improve the diagnostic accuracy of migraine.

\section{Methods}

A cross sectional descriptive study was conducted in a group of 709 outpatients with headache. The physical signs were named as A-G. These were carefully observed certain gestures exhibited by patients themselves when they describe their headache.

\section{Results}

Sign A (pointing right side of the forehead) and sign B (pointing left side of the forehead) were significantly higher in patients with migraine (Sign A positive-123/339, Chi square-15.784, p < 0.001; Sign B positive-146/339, Chi square-20.813, $\mathrm{p}<0.001$ ). Sign $\mathrm{F}$ (keeping the head on a table) was significantly higher in patients with nonmigraine headache (Sign F positive-132/370, Chi square$12.954, \mathrm{p}<0.001)$. Sign A was more commonly associated with unilateral, severe headache which lasted for a longer period of time. However sign B was more commonly associated with unilateral, severe headache only. Sign $C$ was significant in patients who had bilateral headache in both migraine and non-migraine groups than unilateral headache.

\section{Conclusions}

It is concluded that pointing right or left side of forehead when the patient describes his or her headache is a characteristic sign of migraine. Keeping the head on the table during an attack of headache is not a characteristic sign of migraine.

Published: 18 September 2014

doi:10.1186/1129-2377-15-S1-J11

Cite this article as: Samarakoon and Munasinghe: EHMTI-0371. A new physical sign in migraine 'pointing forehead'. The Journal of Headache and Pain 2014 15(Suppl 1):J11.
Submit your manuscript to a SpringerOpen ${ }^{\circ}$ journal and benefit from:

- Convenient online submission

- Rigorous peer review

- Immediate publication on acceptance

Open access: articles freely available online

- High visibility within the field

Retaining the copyright to your article

Submit your next manuscript at $>$ springeropen.com

\section{SpringerOpen ${ }^{\odot}$}

(C) 2014 Samarakoon and Munasinghe; licensee Springer. This is an Open Access article distributed under the terms of the Creative Commons Attribution License (http://creativecommons.org/licenses/by/2.0), which permits unrestricted use, distribution, and reproduction in any medium, provided the original work is properly cited. 